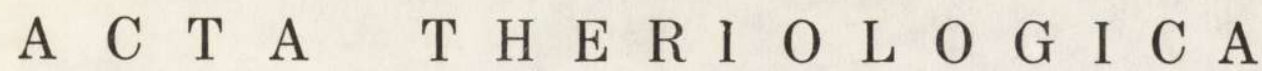 \\ VOL. 19, 17: 259-272.

\section{Renewal of Burrows by the Common Vole as the Indicator of its Numbers}

[With 2 Tables \& 4 Figs.]

\begin{abstract}
It was attempted to find out whether a correlation exists between the number of renewed burrows and number of the common vole Microtus arvalis ( $\mathrm{P}$ a 11 a s, 1779) since this criterion is used as a relative method of estimaing vole numbers. During two years 6 sampling trials, each lasting one month, were carried out on one hectare lucerne plots. The renewal of burrows was determined in one and two days after covering them up, and the number of voles was estimated by the CMR method. It was found that when all burrows are covered up on a definite plot a correlation exists between the number of renewed openings and number of voles. The accuracy of this relative method of estimating numbers based on the process of burrows renewal depends on the area of the sample and time left for the renewal: with the increase of sampling area the value of correlation coefficients increases, and after two days higher coefficients were found that after one day. The values of correlation coefficients undergo seasonal changes reaching the maximum in August and September. The number of burrows falling for one vole shows considerable seasonal variations and hence the number of covered burrows cannot corresponds to the number of voles. On the other hand, the number of renewed burrows per one individual has a rather constant value (mean 1.8). The error in the estimation of numbers arising from the assumption that one renewed burrow corresponds to 1.8 voles amounts to $\pm 50 \%$, and in some cases even to $100 \%$, depending on seasonal changes of vole activity.
\end{abstract}

\section{INTRODUCTION}

One of the methods employed for the estimation of relative numbers of Microtus arvalis ( $\mathrm{P} \mathrm{allas}, 1779$ ) is based on the number of renewed burrow openings. The method depends on covering up all burow openings on the investigated plot and counting renewed burrows next day. It is assumed that the number of voles is in approximation equal to half of the number of renewed burrows (R o mankowowa et al., 1969). This method is employed in several modifications by the plant protection service in Poland (Romankowowa, 1970), Soviet Union (Poljakov, 
1961) and Czechoslovakia (D r a chovska, 1959). In Poljakov's method the estimation is based on the analysis of 10 randomly selected colonies from 1 ha area, while in Czechoslovakia the result is based on the analysis of 3 one-are plots. In other modifications plots of various size are regarded as the representative area for the studied terrain. $\mathrm{R}$ o $\mathrm{m}$ a $\mathrm{n}-$ kowowa et al. (1969) carried out comparative estimations of these modifications in order to find out the size of sampling plot which gives a sufficiently low error of numbers estimation. It was found that the highest agreement in the estimation of numbers is obtained either from one large plot, a dozen or so one-are plots randomly selected, or by estimation of numbers on the basis of number of colonies in the period of population growth.

However, nane of these methods is universal or accurate since all assume a stiff principle of estimation not adequate to the variability of burrow making, which depends on the type of plantation, on the season and degree of penetration of the habitat by voles. The obtained results could be more accurate after taking into account the biology of the process of colony formation. A colony of voles corresponds to a group of burrow openings leading to underground chambers built for nests, feeding or defense (Poljakov, 1961). Openings of these burrows are connected with ground pathways leading to feeding places which limit the area of the colony ( $\mathrm{B}$ a shenina, 1962). Seasonal variability of colonies is particularly well marked in annual plantations. On the other hand, in perennial cultures, which are a permanent habitat, the colonies reach a high degree of complication ( $\mathrm{K}$ a r a s e va, 1957; $\mathrm{Kr}$ a to $\mathrm{chvil}$ et al., 1959).

The common employment of the method of burrow renewal for estimating vole numbers requires determination of its accuracy. Since the estimations which have been carried out hitherto ( $R$ om a n k ow ow a et al., 1969) are indirect it was attempted to investigate the principle of the method on the basis of real vole numbers. Thus the study was aimed at the ascertainment whether a correlation exists between the number of renewed burrows and vole numbers, whether this correlation is constant at different time, and whether the number of renewed burrows falling for one individual is a constant value.

\section{AREA AND METHOD OF INVESTIGATIONS}

The investigations were carried out on 2 one hectare plantations of lucerne (fields $A$ and $B$ ) in Eomna near Warsaw. Each of the fields surrounded by a fence not penetrable for small rodents was inhabited by a population of voles of different density and showing typical changes of population parameters in the year cycle. These populations were studied in respect of population dynamics, age structure, 
intensity of reproduction, spatial structure, etc., within the programme of investigations of the Institute of Ecology, Polish Academy of Sciences. For these purposes the voles were trapped into live traps. The captured individuals were marked and released at the spot according to $C M R$ principles.

At the beginning of the investigations 76 points of trappings were set at the field $A$ and 121 points at field $B$. Each trapping point consisted of three live traps secured from atmospheric influences by a wooden box. Initially the trapping points were localized at the centre of colonies assuming that from among the inidividuals whose areas overlap the colony most often will be trapped its real inhabitants. Later in relation to the development of the population the number of trapping points was increased, but even then all newly formed colonies were included. For example on the field $A$ containing 110 trapping points 18 colonies were without boxes (August 1972), and in field $B$ containing 125 trapping points 28 colonies were without them (October 1972).

The voles were trapped for two days every week and twice in a day (morning and evening).

The data collected during trappings by means of CMR method were analyzed with the method of „Calendar of Catches « (A n drzejewski, 1969). This method enabled accumulation of the following information: number of voles staying in the studied area in a given time, and number of individuals and their captures in particular points at the same time.

The preliminary series of investigations were carried out in September 1970 in order to follow the dynamics of burrow renewal. For this purpose $\mathbf{5}$ colonies were selected, rather of simple structure, as judged by a small number of burrows (mean 4 to 5). The openings labelled with numbers were covered up in such way that voles could renew them without great energy expenses, i.e., the soil was pushed into the opening and slightly treaded down. The covered burrows were inspected at various intervals (after 4, 8 and 12 hours) and the renewed ones were counted. The second experiment was aimed at the determination of the course of burrow renewal after repeated covering them up every $24 \mathrm{hr}$ for 8 days. This experiment was carried out on 10 randomly selected colonies.

The main series of investigations was carried out in the years 1971-1972. It included 6 one-month samplings: 2 in field $A$ in July 1971 and August 1972, and 4 in field $B$ - September 1971, March/April 1972, July 1972 and October/November 1972. These investigations were aimed mainly at finding out whether a correlation exists between the number of renewed burrows and number of voles. Each sampling corresponding to the area of one hectare was carried out gradually during one month. Since covering up the openings of all burrows required a lot of time this was usually done on a part of the field (in most cases 25 ares) in the period between days of trappings. The samplings were made independently of atmospheric conditions and in effect one month sample corresponds to the mean weather during this month. In order to reduce the error related to finding out burrows the whole fields were divided into one are plots. The fence was labelled every $10 \mathrm{~m}$ and by joining these points with string a chequered pattern was obtained for the whole field. On these one-are plots obtained in such way all burrow openings were found out and marked on the plan of the field. Then the openings were covered up with soil and the spots marked with flour. This form of burrow marking, not affecting soil or voles, considerably facilitated the work. In $24 \mathrm{hr}$ after covering up the burrows the number of renewed openings was determined, the process being rpeated at $48 \mathrm{hr}$. The results were also noted on 
the plan. In such way the following data were obtained: number of renewed burrows, number of covered up burrows, and the graphical picture of burrows situation on the field.

\section{RESULTS}

\subsection{Activity in Burrows Renewal}

The results of the first experiment, aimed at the finding out the rate of burrows renewal, indicate a considerable activity of voles in burrowing. It was observed that after 4 hours following burrows covering already $60 \%$ of openings were renewed. The remaining openings, probably used less frequently by voles, were renewed at a much slower rate. During 12 hours the voles renewed further $10 \%$ of burrows. At the same time some new burrow openings were formed.

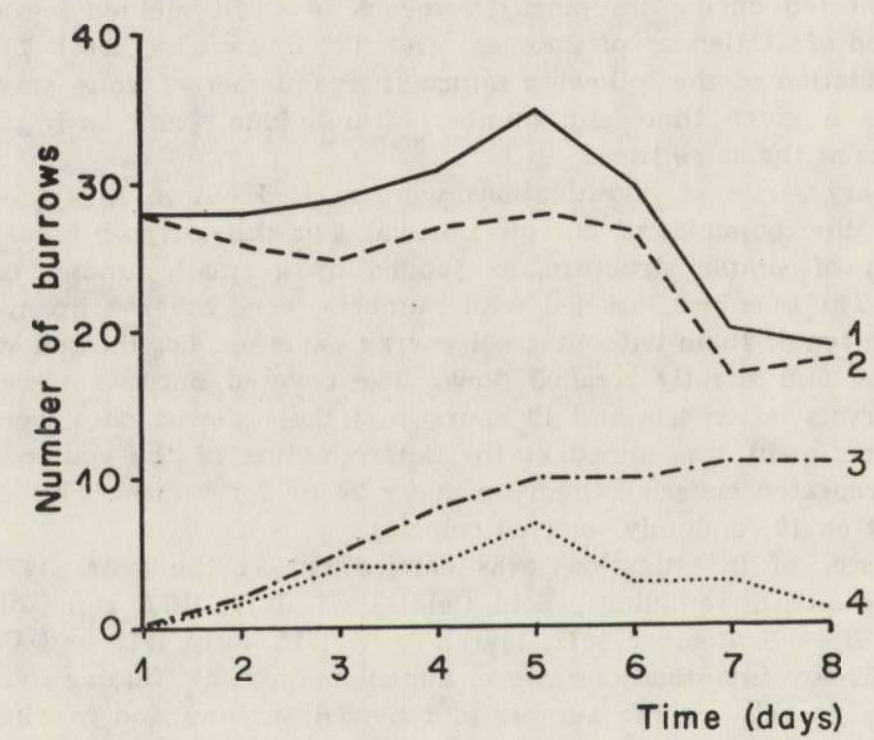

Fig. 1. Changes in the intensity of burrow renewal in 10 colonies during 8 days of the experiment.

1 - number of renewed burrows in relation to all covered up burrows; 2 - number of renewed burrows in relation to "old " burrows; 3 - number of new burrows; $4-$ number of renewed burrows in relation to new burrows.

This phenomenon, leading to complication of the structure of colony, occurred more distinctly in the second experiment aimed at the determination of the course of burrow renewal after repeated covering up. The voles gradually increased the size of the colony by $15 \%$ of burrows in relation to the number observed at the first covering up (Fig. 1). After 5 days a reduction in the intensity of burrow renewal and formation of 
new burrows was observed. It is possible that frequent and prolonged covering up the openings stimulated at first the studied process, but later it disturbed the activity of voles to such extent that the animals leaved the colony.

\subsection{Correlation Between the Number of Renewed Burrows and Number of Voles}

The analysis was carried out for 5 one-month samplings in order to establish a correlation between the number of voles and number of renewed burrows for a given area after 24 and $48 \mathrm{hr}$. The verified values of correlation coefficients, which permit to establish the degree of

Table 1

The values of correlation coefficients $r$ for the number of renewed burrows and number of voles as calculated for different variants.

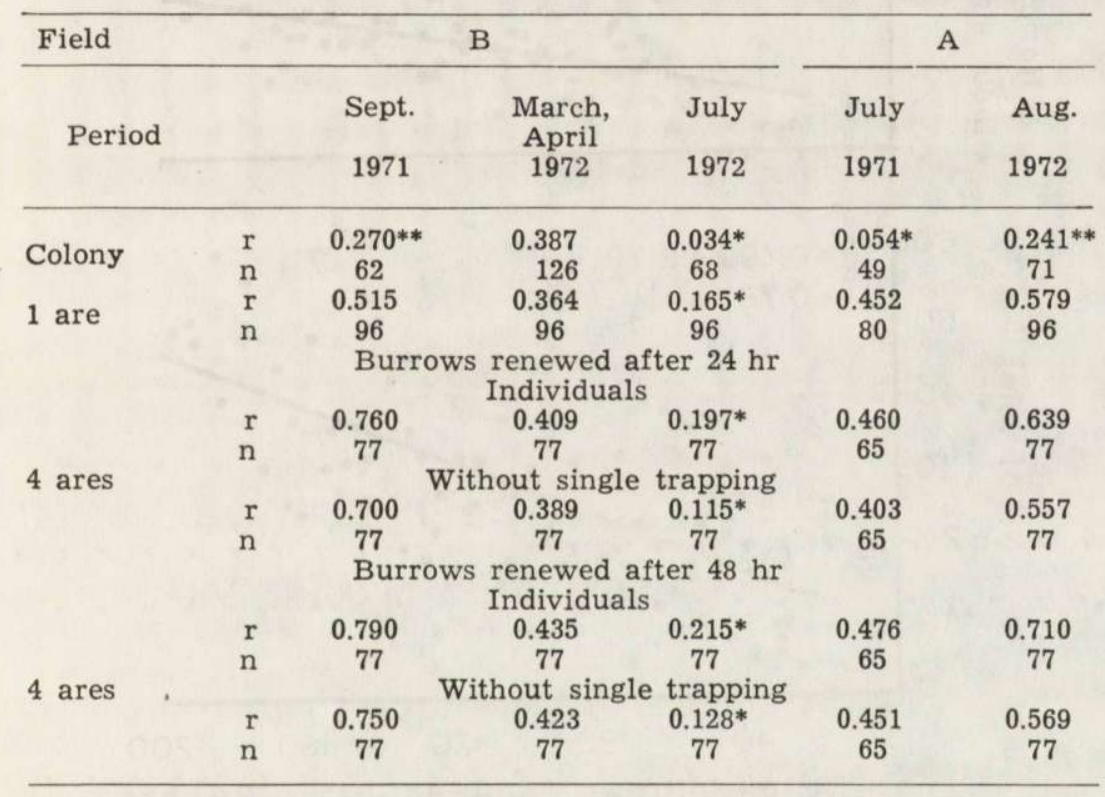

* Non-significant at $\mathrm{P}=0.05$. ${ }^{* *}$ At the border of significance at $\mathrm{P}=0.05$.

relationship between studied parameters $(\mathrm{O} \mathrm{k} \mathrm{t} \mathrm{a} \mathrm{b} \mathrm{a,} \mathrm{1966),} \mathrm{are} \mathrm{listed} \mathrm{in}$ Table 1. The coefficients and regression lines for the highest coefficients are shown in Figs 2 and 3.

The correlation was investigated for the natural area occupied by a vole colony, for one-are plots and for four-are plots in several repeats for each analyzed sample. The one-are and four-are plots were established independently of the distribution of colonies. In order to investigate the 
correlation for particular colonies those should be selected which had trapping points and a definite boundary of burrow distribution. It was mentioned that the individuals captured in the trapping point standing on the area of the colony during sampling were treated as inhabitants of this colony. For one-are plots the correlation coefficients were calculated in relation to the number of burrows renewed after one day only, for four-are plots - after 24 and $48 \mathrm{hr}$.

When analyzing the captures of individuals in trapping points it was found that apart from voles trapped several times the highest number
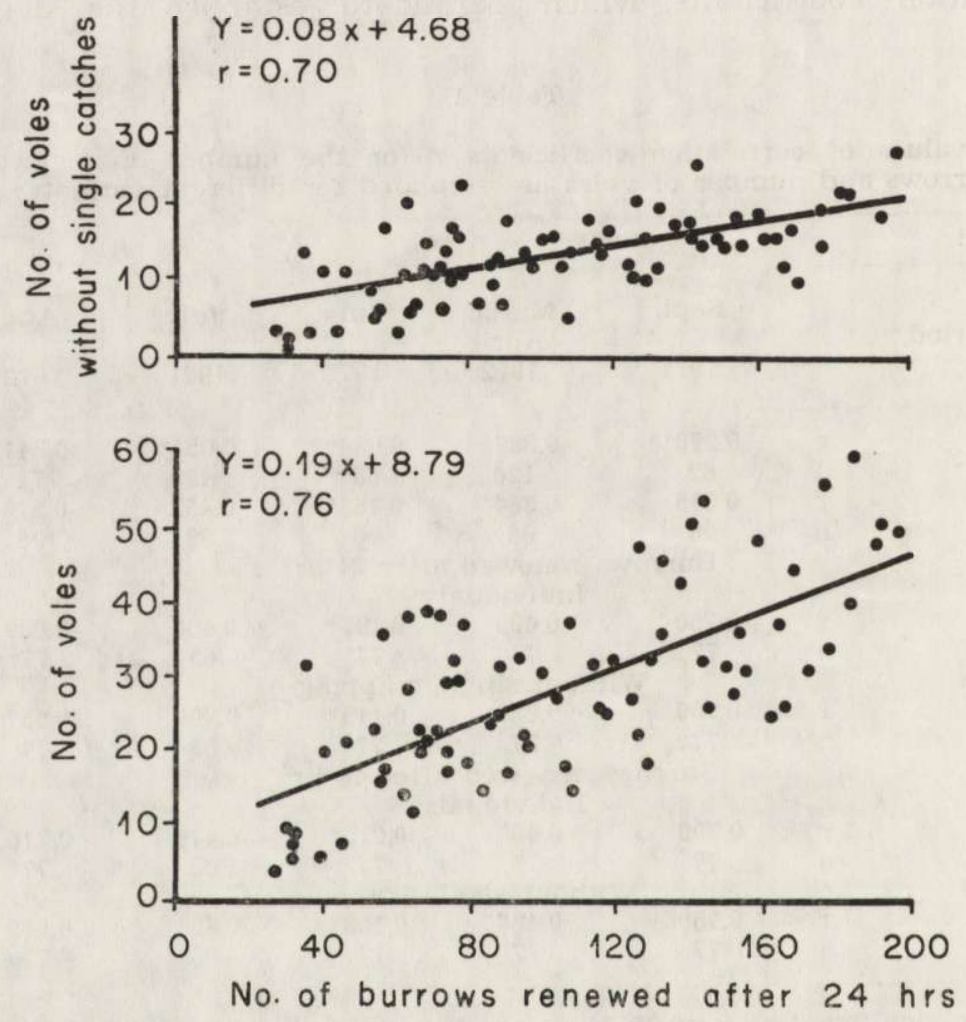

Fig. 2. Correlation between the number of renewed burrows after 1 day and number of voles on the area of 4 ares (September 1971, field B).

of individuals was captured only once. In effect it was concluded that individuals trapped more than once at a given point inhabit most likely a given colony. In such way four combinations were obtained in which the number of burrows renewed after $48 \mathrm{hr}$ and number if individuals captured on a given area showed the highest correlation (Table 1). 
The values of correlation coefficients vary in relation to the size of the area and the season of sampling (Table 1). With increased area the value of correlation coefficients increase reaching the highest figures for four-are plots. The correlation calculated in relation to the number of voles in a colony is low and does not reach statistical significance for samplings in July 1971 field $A$, and July 1972 field $B$. At the same time the highest value of the correlation coefficient for this group $(r=0.387)$ was found for the sampling in March/April 1972 field B. For four-are and one-are plots the coefficients of correlation are statistically signifi-
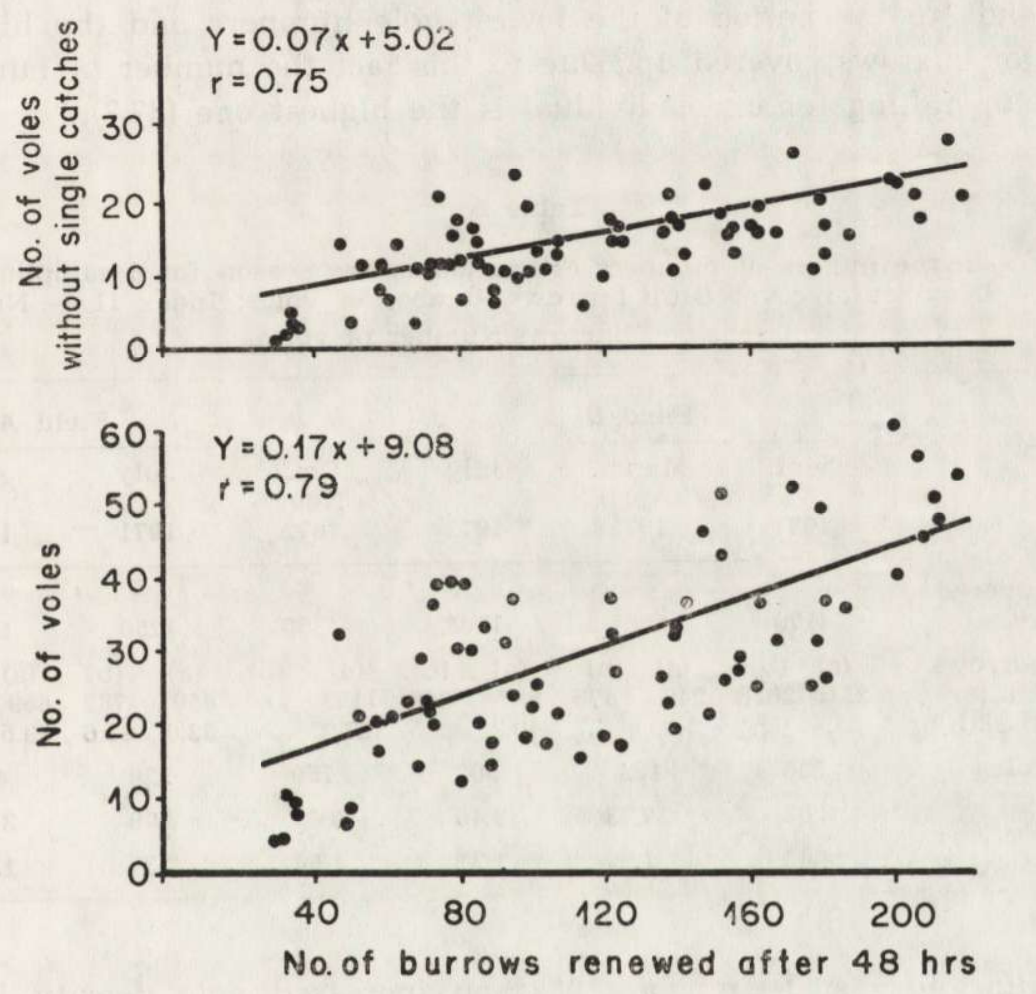

Fig. 3. Correlation between the number of renewed burrows after 2 days and number of voles on the area of 4 ares (September 1971, field $B$ ).

cant, except July sampling (field $B, 1972$ ). During the season the highest values for the studied correlation were found in August and September, and the lowest in July (field $B, 1972$ ). Low, but significant values of correlation coefficients were found for samplings in July 1971 field $A$ and March/April 1972 field B. 


\subsection{Seasonal Changes of Indices of Burrows Renewal}

In order to investigate seasonal changes in the process of burrows renewal in the years $1971-1972$ the following data were calculated for each sampling: per cent of burrows renewed after 24 and $48 \mathrm{hr}$, number of burrows covered up falling for one vole, and number of renewed burrows falling for one vole (Table 2). These indices describe in a comparable way the relationships between voles and burrows on one hectare area and for this reason they represent a basis for the estimation of seasonal variability. The highest percentage of renewed burrows was observed in the spring sampling (March/April 1972 field B). This corresponds to the period of the lowest vole numbers and the highest density of burrows covered up. Due to this fact the number of burrows covered up falling for one individual is the highest one (37.7).

Table 2

Changes in the indices of numbers estimation in the season for 6 samplings. Index I - Number of covered up burrows/Number of voles; Index II - Number of renewed burrows/Number of voles.

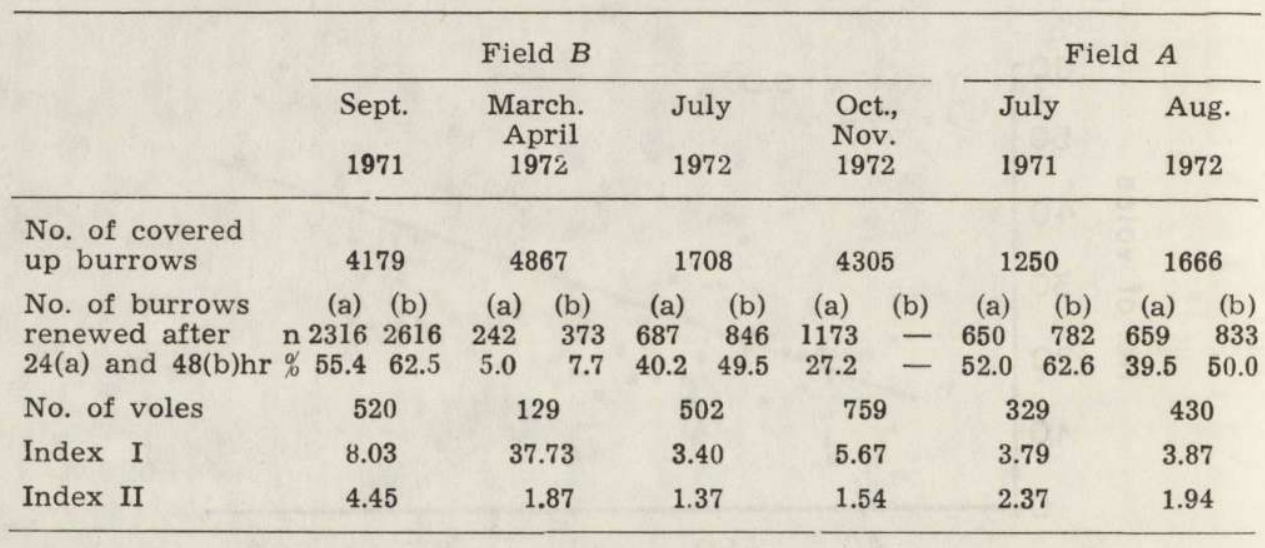

According to Bashenin a (1962) an increased vole density leads to the increase of activity of the population in the process of colony formation. A similar phenomenon was observed in field $B$ in 1972: between spring and summer samplings a fourfold rise in the population numbers was observed being accompanied by a similar increase in the number of burrows. On the other hand, in the period between summer and late autumn the number of burrows also increased fourfold while the rise of the population numbers was only 1.5 times.

The samplings carried out on both fields in summer are characterized by a high percentage of renewed burrows, although the values observed 
in 1972 are lower by approximately $10 \%$ in comparison with 1971 . Taking into consideration the density of vole population a decrease in the activity of burrow renewal was observed in late autumn. This decrease is particularly distinct when comparing September sampling (1971, field $B$ ), for which the highest percentage of burrows renewal was observed $(55.4 \%$ after $24 \mathrm{hr}, 62.5 \%$ after $48 \mathrm{hr}$ ), with October/November 1972 sampling of this field showing then a higher vole density. The data indicate a high activity of voles in burrow renewal and colony building in the compared periods.

The number of covered up burrows falling for one vole changes considerably in relation to season, while the value describing the number of renewed burrows falling for one vole ranges 1.37 and 2.37 (mean 1.8), although it reaches 4.45 for the September sampling. All these results

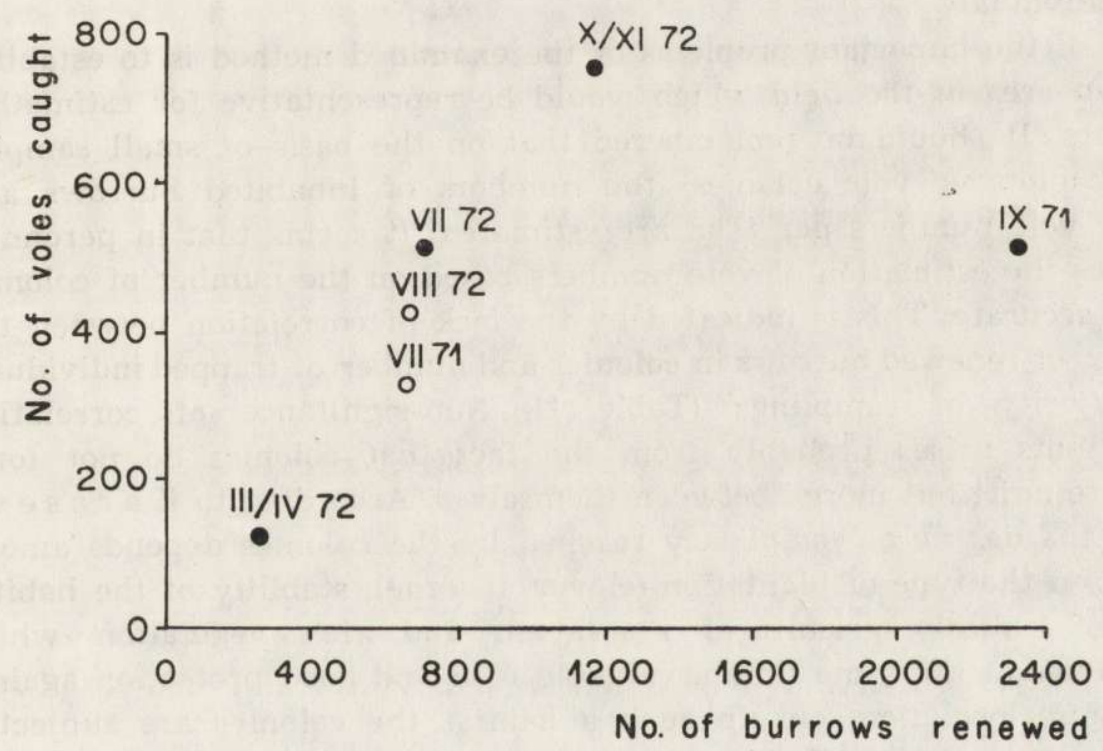

Fig. 4. Relationship between the number of renewed burrows after 1 day on the area of 1 hectare and the number of voles trapped on this area. O-field $A$, $\bullet-$ field $B$.

deviate from the data of literature according to which 2 renewed burrows fall for one vole ( $\mathrm{Poljakov}, 1961)$. Hence the error arising from the employment of the latter value reaches $\pm 50 \%$, and in conditions favouring burrowing even $100 \%$.

It was demonstrated that a direct relationship exists between the number of renewed burrows and real number of voles estimated on the basis of "calendar of catches", in samplings in which approximately 1.8 renewed burrow falls for one vole (Fig. 4). On account of a small number 
of samples the correlation coefficient cannot be calculted. On the other hand, the September samplings (1971 field $B$ ) in which the number of renewed burrows falling for one vole is two times higher than expected, deviate considerably from the remaining samplings.

\section{DISCUSSION}

The principal assumption of the tested method of numbers estimation on the existence of correlation between the number of renewed burrows and number of voles has been confirmed. At the same time it was found by the analysis of the value of correlation coefficients that the credibility of the method depends on the sampling area, time of burrow renewal (1 or 2 days) and theoretical assumptions used for recalculation of burrows into individuals.

One of the important problems of the examined method is to establish such an area of the field which would be representative for estimating numbers. It should be remembered that on the basis of small samples (a few plots or vole colonies) the numbers of inhabited burrows and iinally vole numbers per 1 ha are estimated. It seems that in perennial cultures the estimation of vole numbers based on the number of colonies is not accurate. This is indicated by the lack of correlation between the number of renewed burrows in colonies and number of trapped individuals in majority of samplings (Table 1). Non-signifance of correlation coefficients arises probably from the fact that colonies do not form separate units but merge between themselves. According to $\mathrm{K}$ a $\mathrm{r}$ a s e v a (1957) the degree of complicacy reached by the colonies depends among others on the type of plantation (clover, lucerne), stability of the habitat (lack of radical agricultural measures), and rich vegetation which constitutes at the same time a valuable food and good protection against predators, insolation, etc. In such a habitat the colonies are subjected to succession of the inhabitants. Every generation of voles enlarges the system of burrows, increases the number of openings and in effect the colonies occupy a larger area. Similarly, in the preliminary studies a fast rate of renewal and enlargement of the colony was observed.

In proportion to the sampling area (one or four ares) the value of correlation coefficients for the tested relationship increases (Table 1). Hence the larger area the higher probability of estimation of the real number of voles. $\mathrm{R}$ o m a n k o w o w a et al. (1969) suggest that the number and size of plots should be established in relation to the number af inhabited burrows and uniformity of arrangement of the colony.

On the other hand, relatively low coefficients of correlation caused by discrepancies of results during repeated samplings may be due to the 
fact that some colonies were without trapping boxes and some trapping boxes stood outside colonies. Hence a large number of trapped individuals might not inhabit the colony and they were captured incidentally. In the vole population there is always a group of migrating individuals moving over the whole area in distinction to majority of permanent inhabitants which penetrate barley 5 to $6 \mathrm{~m}$ of the area within the colony (B a s h e$\mathrm{n}$ in a, 1962). Single trappings are characteristic for migrating individuals but the elimination of these trappings has not increased the value of correlation coefficients. Another error may be due to the inaccuracy in finding out burrow openings. With the increase of examined area the discrepancies between number of burrows and number of voles may compensate each other increasing correlation coefficients. This again confirm the idea that with a larger area the estimation of numbers is more representative for the terrain of a high vole density.

Moreover it was found that the number of renewed burrows counted after 2 days gives higher values of correlation coefficients. This indicate that accuracy of the method can be improved by prolonging up to 2 days the period between covering up the openings and counting renewed burrows.

However, taking into consideration the purpose of this study the most important are the data obtained for the area of 1 ha, since they describe the situation most accurately. According to the data in Table 2 it is possible to estimate the relationship between the number of covered up or renewed burrows and vole numbers. The first index recalculated for one vole shows considerable variations between samplings. According to $\mathrm{B}$ a s h e $\mathrm{n}$ in a (1962) the value of this index depends on vole numbers and on several other factors. Particulary drastic discrepancies between the number of burrows and number of voles were observed in spring. The lowest number of voles was accompanied by the highest number of covered up burrows (37.7 per vole), some of them being certainly out of use. Estimation of numbers in that period gave very high values considerably exceeding the real figure. In the period of population increase a certain relationship could be observed between the number of voles burrows. However, the increase is not strictly proportional and any estimation gives only approximative values.

The relative method of numbers estimation depends on counting of renewed burrows and is based on a direct and rather constant relationship between the number of renewed burrows and number of voles. Variations of this value are caused mainly by changes in the activity of voles. A higher activity of voles in burrows renewal gives a higher index, and reverse. The activity of voles in burrowing depends not only on the density but also on the abundance and availability of food ( $\mathrm{K}$ a r a s e va, 
1957). The lowest value of this index was observed in summer with a rich vegetation. At abundant plant cover the voles run to the places of feeding mainly on the surface and the underground passages are less utilized. At the same time the colonies show a simpler structure $(\mathrm{K}$ a r as eva, 1957). In early autumm (September 1971, field $B$ ) an abrupt increase in the activity of voles in burrows renewal was observed. That period was very unfavourable for lucerne plantations on account of drought. It is possible that by then voles lost easily available food and protection thus changing from the surface to underground movements. Hence the burrows leading to feeding places were constructed. In late autumn a decrease in the activity of voles at their high density was caused by the deterioration of weather (fall of temperature) and reduced sexual activity of rodents.

When operating the number of renewed burrows in plant cultures of the lucerne type and assuming that one renewed burrow falls for 1.8 vole the error of the method amounts to $\pm 50 \%$, and sometimes even exceeds $100 \%$, depending on seasonal changes of voles activity. This error is not large when we estimate losses at a low vole density but may be significant in autumn at high vole numbers and in spring when prognostic values are required. The problem is so important that further studies are essential in other types of plantations to verify changes of the above mentioned index.

Acknowledgements: I wish to express my thanks to Dr. R. Andrzejewski and Professor K. Petrusewicz for scientific guidance and to Dr. K. Andrzejewska and Dr. T. Wierzbowska for help in preparation of the paper.

\section{REFERENCES}

1. Andrzejewski R., 1969: Analiza wyników połowów drobnych ssaków metodą "Kalendarza Złowień «. Zesz. Nauk. Inst. Ekol. PAN 2: 1-104. Warszawa.

2. Bash enina N. V., 1962: Ekologia obyknovennoi polevki, nekotorye čerty ej geografičeskoj izmenčivosti. Izd. Moskv. Univ.: 1-309. Moskva.

3. Drachovska M., 1959: Prognosa a diagnosa w ochronie rostlin. Vestn. csl. Akad. zemed. Ved.: 445-450. Praha.

4. Karaseva E. V., 1957: Sezonnye i stacialnye osobennosti stroenia nor i kolonii obyknovennoi polevki srednei polosy SSSR. Fauna i ekol. gryz. 5: $67-75$.

5. Kratochvíl J. et al., 1959: Hraboš polni (Microtus arvalis). Ceskoslov. Akad. Ved.: $1-359$. Praha.

6. Migula P., Grodziński W., Jasiński A. \& Musiałek B., 1970: Vole and mouse plagues in south-eastern Poland in the year 1945-1967. Acta theriol., 15, 16: 233-252.

7. Oktaba W., 1966: Elementy statystyki matematycznej i metodyka doświadczalnictwa. Państw. Wyd. Nauk.: 1-310. Warszawa.

8. Poljakov I. J., 1961: Vrednyje gryzuny i borba s nimi. 1-261. Moskva. 
9. R om a n kowowa A., P iekarczyk K. \& Gra la B., 1969: Krytyczne uwagi o metodach oceny liczebności nornika polnego (Microtus arvalis $\mathrm{P}$ a 11.) dla celów prognostycznych. Biul. Inst. Ochr. Rośl. 44: 353-360.

10. Romankowowa A., 1970: Liczebność nornika polnego (Microtus arvalis P a 11.) w Polsce w roku 1969 i prognozy na rok 1970. Biul. Inst. Ochr. Rośl., 46: $61-73$.

11. Skurat owicz W., 1963: Biologia i zwalczanie gatunków szkodliwych. Państw. Wyd. Roln. i Leśń., 1-172. Warszawa.

Accepted, February 15, 1974.

Institute of Ecology,

Polish Academy of Sciences,

Dziekanów Leśny, 05-150 Łomianki, Poland.

\section{Anna LIRO}

\section{ODNAWIANIE NOR PRZEZ MICROTUS ARVALIS (P A L A S, 1778) \\ JAKO WSKAŹNIK OCENY JEGO LICZEBNOSCI}

\section{Streszczenie}

Sprawdzano, czy zachodzi rzeczywista korelacja pomiędzy liczbą odnowionych nor a liczebnością norników, która stanowi podstawowe założenie względnej metody oceny liczebności. W tym celu w ciągu 2 lat wykonano sześć jednomiesięcznych prób na dwóch jednohektarowych polach lucerny. Tę zasadniczą serię badań uzupełniono doświadczeniami, które pozwoliły zaobserwować szybką dynamikę odkopywania nor i rozbudowywania kolonii (Ryc. 1).

Onawianie nor liczono po jednej i dwóch dobach od ich zasypania, a liczbę norników oceniano metodą $C M R$. Korelacje badano dla różnej powierzchni, którą stanowiły kolonie norników, poletka jednoarowe i czteroarowe w kilkudziesięciu powtórzeniach dla każdej analizowanej próby. Dla powierzchni czteroarowej korelowano ze sobą dane w czterech kombinacjach (Tabela 1). W wyniku stwierdzono, że jeżeli na określonej powierzchni zasypano wszystkie nory to istnieje korelacja pomiędzy liczbą odnowionych nor a liczbą norników. Przy czym dokładność względnaj metody oceny liczebności opartej a proces odnawiania nor zależy od wielkości areału próby i pozostawionego czasu na odnawianie nor w taki sposób, że: wraz ze wzrostem areału próby rośnie wartość współczynnika korelacji, po dwóch dniach odnawiania nor uzyskano wyższe wartości współczynników korelacji niż po jednym (Tabela 2).

W celu prześledzenia sezonowych zmian w procesie odnawiania nor wyliczono dla każdej próby: \% nor odnowionych po 24 i 48 godzinach w stosunku do zasypanych, liczbę nor zasypanych przypadającą na jednego nornika, liczbę nor odnowionych przypadającą na jednego nornika (Tabela 3). Stwierdzono, że liczba nor przypadająca na jednego nornika nie może być miernikiem liczebności norników. Natomiast liczba nor odnowionych przypadająca na jednego osobnika ma wartość względnie stałą (średnio 1,8) (Tabela 3). 
Zbadano, czy zachodzi wprost proporcjonalna zależność pomięrzy liczbą odnowionych nor na powierzchni hektara a rzeczywistą liczbą norników oszacowaną w oparciu o metodę CMR. Pomiędzy próbami, dla których na jednego nornika przypada około 1,8 odnowionej nory, występuje badana zależność (Ryc. 4).

Błąd w ocenie liczebności wynikający $\mathrm{z}$ założenia, że na jedną odnowioną norę przypada 1,8 nornika, równa się $\pm 50 \%$, czasem $100 \%$ w zależności od sezonowych zmian aktywności norników. 